\title{
v-Crk, an effector of the nerve growth factor signaling pathway, delays apoptotic cell death in neurotrophin- deprived PC12 cells
}

\author{
Robert H. Glassman ${ }^{1,2}$, Barbara L. Hempstead', \\ Lisa Staiano-Coico ${ }^{3}$, Melissa G. Steiner ${ }^{3}$, Hidesaburo \\ Hanafusa $^{2}$ and Raymond B. Birge $\mathrm{e}^{2,4}$ \\ ${ }^{1}$ Division of Hematology-Oncology, Department of Medicine, The New York \\ Hospital-Cornell University Medical College, 1300 York Avenue, New York, NY \\ 10021, USA \\ 2 Laboratory of Molecular Oncology, The Rockefeller University, 1230 York \\ Avenue, New York, NY 10021, USA \\ ${ }^{3}$ Division of Otorhinolarngology, Department of Surgery, The New York \\ Hospital-Cornell University Medical College, 1300 York Avenue, New York, NY \\ 10021, USA \\ ${ }^{4}$ corresponding author: Laboratory of Molecular Oncology, The Rockefeller \\ University, 1230 York Avenue, New York, NY 10021. e-mail: \\ birger@rockvax.rockefeller.edu
}

Received 29.2.96; revised 29.5.96; accepted 21.6.96

Edited by C.J. Thiele

\begin{abstract}
$\mathrm{v}$-Crk is a member of a class of SH2 and SH3-containing adaptor proteins that have been implicated in regulating the TrkA receptor tyrosine kinase and potentiating Nerve Growth Factor (NGF)-mediated neurite outgrowth in pheochromocytoma (PC12) cells (Hempstead et al, Mol. Cell Biol. 14: 19641971). Given the fact that NGF induces both differentiation and survival by binding to TrkA, we examined the rate of apoptotic cell death elicited by NGF-withdrawal in native, v-Crk, and TrkA-expressing PC12 cells. While more than $50 \%$ of native PC12 cells underwent apoptosis within $48 \mathrm{~h}$ of NGF withdrawal, the v-Crk and TrkA-expressing cells were much more resistant to apoptosis under these conditions, whereby approximately 70 and $95 \%$, respectively, of the cells were alive. The ability of v-Crk to delay apoptosis required prior NGF-dependent differentiation, since naive undifferentiated vCrk expressing PC12 cells or cells that express v-Crk mutants that are defective in NGF signaling were not protected from apoptosis during growth factor withdrawal. Moreover, addition of $50 \mathrm{ng} / \mathrm{ml}$ EGF to serum and NGF deprived v-Crk expressing cells, which also causes neurite outgrowth, promoted complete and long-term survival, although such EGF replacement had no neurotrophic effect on wild-type PC12 cells or PC12 cells overexpressing Human Bcl-2. These experiments suggest that v-Crk potentiation of a receptor tyrosine kinase under conditions of growth factor deprivation is essential for preventing apoptosis. However, unlike native PC12 cells, neither v-Crk or TrkA-expressing PC12 cells exhibited a G1 arrest when incubated for 2 weeks in NGF. Thus, v-Crk and TrkA may protect NGF deprived PC12 by preventing cell cycle arrest and hence an aborted entry into a defective
\end{abstract}

cell cycle. Moreover, during NGF-withdrawal, v-CrkPC12 cells exhibited down regulation in MAP kinase and JNK activities while in native cells, these activities increased within 6-8 h after NGF deprivation. Thus, unlike v-Crk-mediated augmentation of differentiation, sustained activation of MAP kinase may not be required for $\mathrm{v}$-Crk-induced cell survival.

Keywords: $\mathrm{SH} 2$ and $\mathrm{SH} 3-$ containing adaptor proteins, TrkA receptor tyrosine kinase, nerve growth factor, Bcl-2, MAP kinase

Abbreviations: NGF: nerve growth factor; EGF: epidermal growth factor; PC12: pheochromocytoma cells; SH2: Src Homology 2; PLC- $\gamma$ : phospholipaseC- $\gamma$; PI-3 kinase: phophatidylinositol-3-kinase

\section{Introduction}

Programmed cell death is an essential feature during development of the nervous system, to eliminate redundant cells and to achieve a precise balance between target cells and neurons. The survival and differentiation of immature neuroblasts in the peripheral nervous system is regulated by the limiting supply of neurotrophic factors (Barde et al, 1989), the best characterized of which is nerve growth factor (NGF) (Thoenen and Barde, 1980). The neural crest-derived rat pheochromocytoma (PC12) cell line has served as a model system to study the role of NGF during neuronal differentiation and survival (Greene and Tischler, 1976, 1982). Upon exposure to NGF, PC12 cells stop dividing, develop neurites, and increase neurotransmitter synthesis so as to acquire a phenotype similar to mature sympathetic neurons (Greene and Tischler, 1982; Rudkin et al, 1989). NGF initiates these effects by binding to its receptor, p140 Trk A, and activating its intrinsic tyrosine kinase activity (Kaplan et al, 1991; Klein et al, 1991). A number of cytoplasmic signaling proteins, including phospholipase $\mathrm{C}-\gamma$ (PLC- $\gamma$ ), phosphatidylinositol-3-kinase (PI-3' kinase), and Shc, which contain either Src Homology 2 (SH2) or Phosphotyrosine binding domains (PTB) (Geer and Pawson, 1995) bind to specific sequences within the auto-phosphorylated TrkA receptor (reviewed in Kaplan and Stephens, 1994). Mutagenesis of the Shc (Y490) and PLC- $\gamma$ (Y785) binding sites on TrkA block NGF-mediated neurite outgrowth demonstrating the importance of receptor phosphorylation in mediating neural differentiation (Obermeier et al, 1994; Stephens et al, 1994). While the signaling pathways that lead to differentiation following NGF addition are reasonably well understood, the molecular mechanisms regulating apoptosis during NGF withdrawal are particularly lacking. 
An emerging hypothesis that may explain mechanisms by which mature neurons activate a suicide program upon withdrawal of NGF suggests that re-activation of mitogenic signals in a post-mitotic neuron can lead to cell death (Rubin et al, 1993). This idea is supported by the observations that cell cycle related genes such as cyclin D1, cyclin A, c-jun and c-fos are upregulated within hours following NGF withdrawal in sympathetic neurons (Estus et al, 1994; Freeman et al, 1994; Meikrantz et al, 1994; Kranenburg et al, 1996). In addition, the induction of dominant negative N17Ras (Ferrari and Greene, 1994) or microinjection of dominant negative FLAG $\Delta 169$ c-Jun in neuronal PC12 cells or primary SCG neurons, respectively, just prior to NGF withdrawal can inhibit apoptosis (Ham et al, 1995). In many cell types, conflicting growth promoting and growth arresting signals can also induce apoptosis, as in the case where p53 transfection into E1Atransformed fibroblasts induces apoptosis (Lowe et al, 1993). Moreover, constitutive expression of c-myc in rat fibroblasts or Chinese hamster ovary $(\mathrm{CHO})$ cells induces apoptosis in cells arrested by a variety of cytostatic manipulations, such as serum deprivation or addition of drugs which inhibit DNA replication (Bissonnette et al, 1992; Evan et al, 1992).

Adaptor proteins, which consist of Src Homology 2 and 3 (SH2 and $\mathrm{SH} 3$ ) domains, link receptor tyrosine kinases such as Trk A with downstream cytosolic effector proteins (Cantley et al, 1991) and are likely integral components of NGF signaling pathways (Park and Rhee, 1992; RozakisAdcock et al, 1992; Hempstead et al, 1994; Matsuda et al, 1994). SH2 domains are conserved motifs of approximately 100 amino acids which recognize and bind tyrosine phosphorylated proteins (Cantley et al, 1991); SH3 domains, compromised of approximately 60 amino acids, recognize proline rich motifs of the general consensus PXXP (Ren et al, 1993). The role of adaptor proteins in apoptotic signaling is largely uninvestigated, although microinjection of Grb3-3, an SH2 deleted isoform of Grb2, triggered apoptotic death in fibroblasts (Fath et al, 1994). We have recently shown that the $\mathrm{v}$-Crk adapter protein potentiates TrkA signaling and accelerates NGF-induced neurite outgrowth in PC12 cells (Hempstead et al, 1994). The v-Crk protein contains avian retroviral Gag sequences fused in frame to cellular sequences containing one $\mathrm{SH} 2$ and one SH3 domain (Mayer et al, 1988) and is derived from an ubiquitously expressed cellular gene, called c-crk, which contains an $\mathrm{SH} 2$ domain followed by two $\mathrm{SH} 3$ domains (Reichman et al, 1992). To further investigate how $\mathrm{SH} 2$ and $\mathrm{SH} 3$ containing proteins influence neurotrophic pathways, we examined the short-term survival of $\mathrm{PC} 12$ cells expressing v-Crk following NGF deprivation. Here we report that $\mathrm{v}$-Crk significantly delays apoptotic death in differentiated PC12 cells following NGF withdrawal. Using mutant v-Crk PC12 cells which are deficient in NGF signaling, we show that the ability of v-Crk to protect PC12 cells correlates with its ability to potentiate TrkA signaling. Moreover, re-stimulation of EGF Receptor in NGF-deprived v-Crk-expressing PC12 cells caused complete and long-term resistance to apoptosis. These results indicate that $\mathrm{v}$-Crk can modulate tyrosine kinase signals in
PC12 cells and may function in a novel anti-apoptotic signaling pathway.

\section{Results \\ Stable expression of v-Crk or TrkA delay cell death in NGF-deprived differentiated PC12 cells}

Ectopic expression of v-Crk in rat PC12 cells augments the rate of neurite outgrowth following treatment with $50 \mathrm{ng} / \mathrm{ml}$ NGF (Hempstead et al, 1994) and potentiates phenotypic differentiation in response to sub-threshold $(1 \mathrm{ng} / \mathrm{ml})$ concentrations of NGF (Figure 1 and (Hempstead, 1994)). Cells maintained under conditions of long-term NGF treatment will be referred to as 'neuronal' PC12 cells throughout the paper. To assess whether v-Crk could also potentiate survival of neuronal PC12 cells as a result of short-term NGF withdrawal, a fluorescence live/death analysis of native PC12 cells or vCrk-PC12 cells was performed following NGF deprivation (Figure 2c, d, g, h and summarized in Figure 3). In the NGFdeprived PC12 cultures, about $60 \%$ of the cells stained ethidium homodimer by $72 \mathrm{~h}$, indicating the cells have lost membrane integrity in the late stages of cell death (Figure $3 b$ ). In contrast, more than $70 \%$ of the $\mathrm{v}$-CrkPC12 cells were impermeable to ethidium homodimer and remained viable as manifested by intracellular esterase activity, assayed by fluorescent activation of calcein AM. Although viability was maintained in v-CrkPC12 cells after growth factor removal, neurite extension was not, with only $10-20 \%$ of cells still

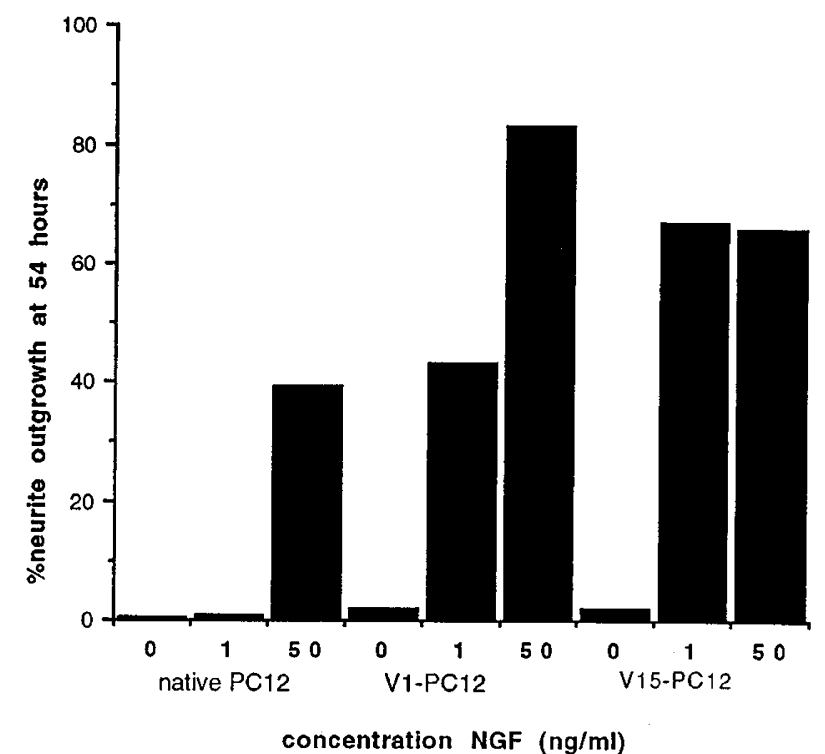

Figure $1 \mathrm{v}$-Crk is an effector of the NGF signaling pathway at $1 \mathrm{ng} / \mathrm{ml}$ NGF PC12 cells stably expressing V-Crk (clones V1 and V15) were maintained on rat-tail collagen coated plates in $3 \%$ serum ( $2 \%$ calf and $1 \%$ horse) and seeded into six well dishes after which either no ligand (0), $1 \mathrm{ng} / \mathrm{ml} \mathrm{NGF}$, or $50 \mathrm{ng} / \mathrm{ml}$ NGF was added for $48 \mathrm{~h}$. Percent neurite outgrowth is expressed as the percentage of cells containing neurite processes greater than two cell bodies (approximately $20 \mu \mathrm{m}$ in diameter). Experiments are the average of triplicate wells. 
expressing neurites of two cell bodies after $72 \mathrm{~h}$ in NGF-free conditions. Cells were also stained with Hoechst 33258, a more conventional means to ascertain apoptotic chromatin condensation (Figure 2a, b, e, f). Herein, several PC12 cell nuclei exhibited punctate chromatin staining following $36 \mathrm{~h}$ of growth factor deprivation, whereas parallel cultures of vCrkPC12 nuclei had uniform, non-condensed chromatin staining (Figure 2 compare panels $b$ versus $f$ ).

\section{Hoechst 33258}

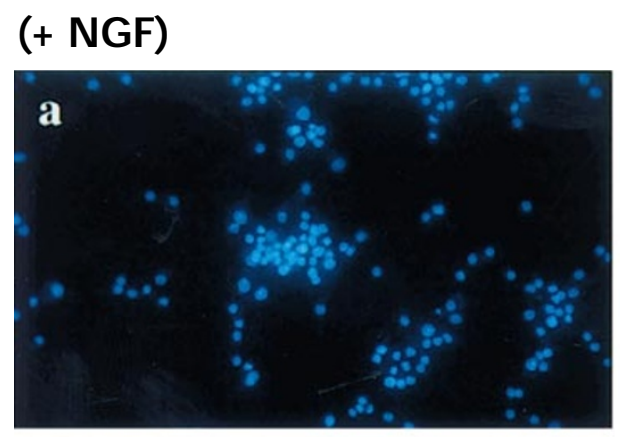

\section{(- NGF)}
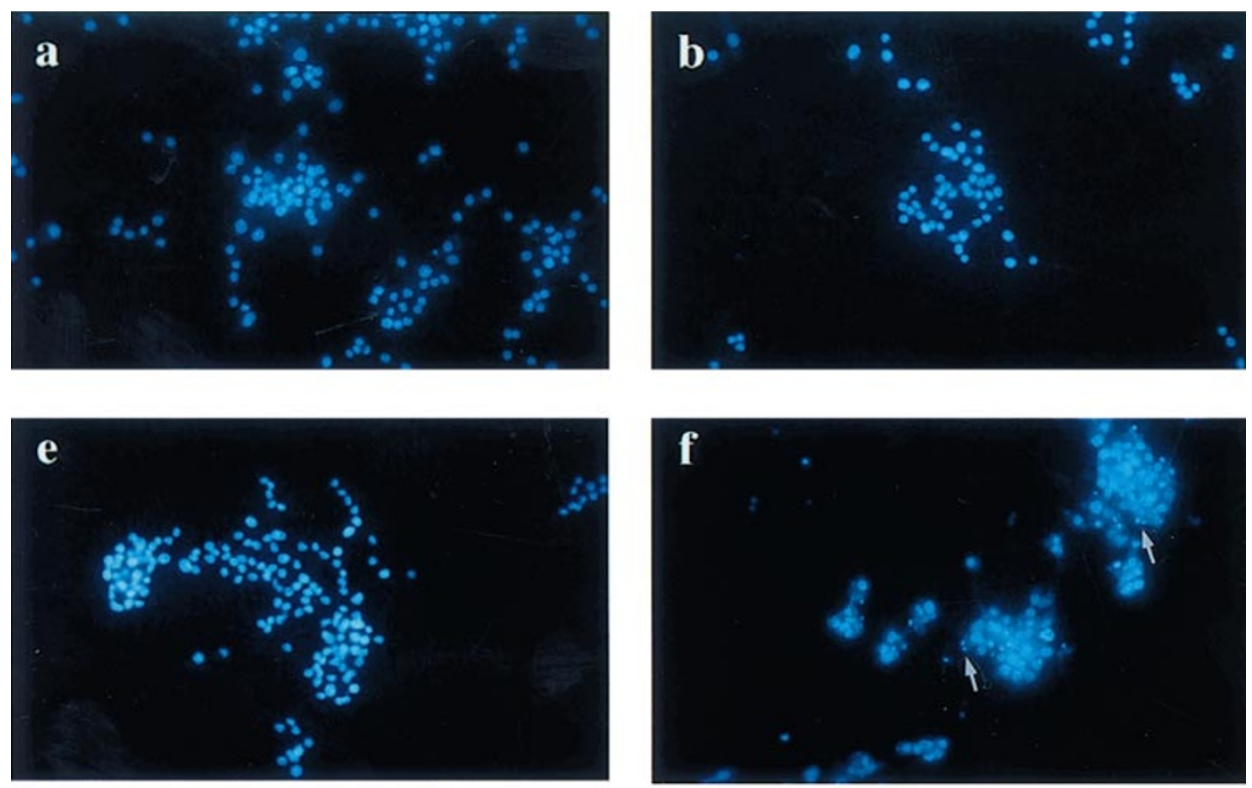

\section{Fluorescence live/ death}

\section{(+NGF)}
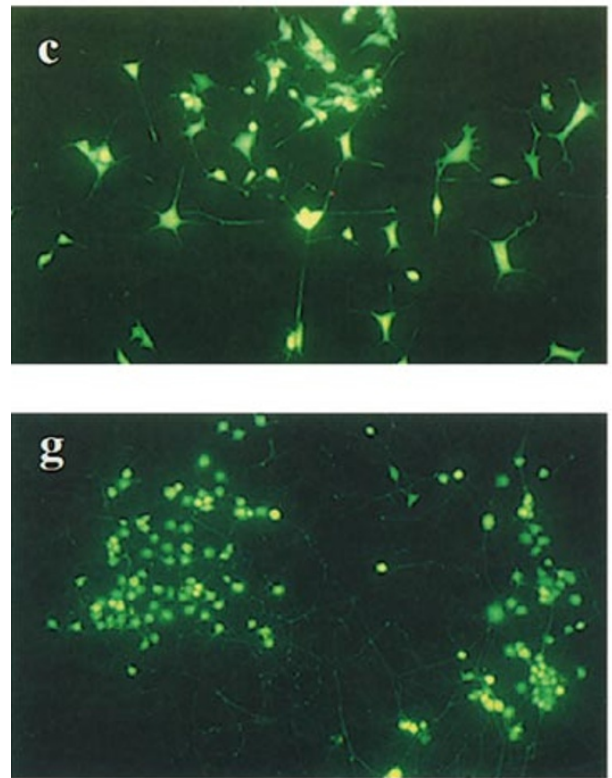

\section{(- NGF)}
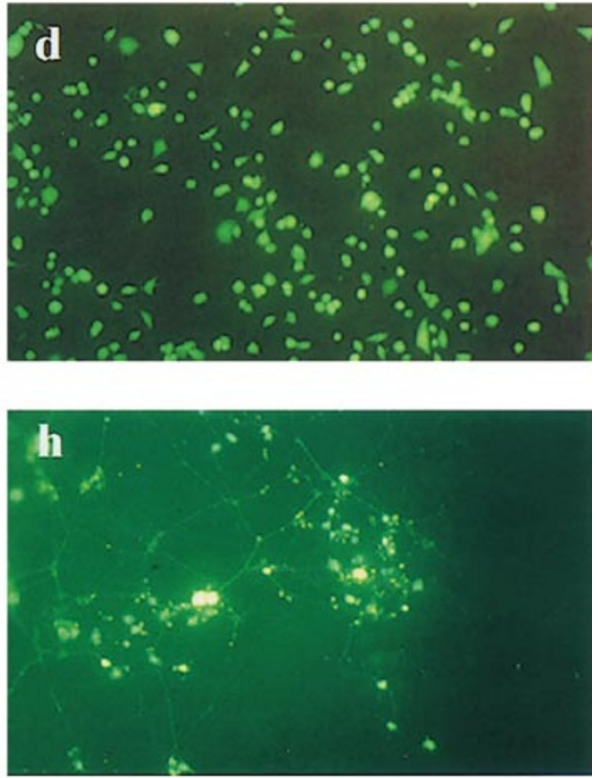

Figure 2 Morphological appearances of v-Crk-expressing PC12 cells and native PC12 cells during NGF withdrawal. Native or v-Crk-expressing PC12 cells were cultured on rat-tail collagen-coated plates and maintained in $3 \%$ serum plus $50 \mathrm{ng} / \mathrm{ml} \mathrm{NGF}$ for 14 days (a, c, e, g) or transferred to serum-free media without NGF for $36 \mathbf{h}(\mathbf{b}, \mathbf{d}, \mathbf{f}, \mathbf{h})$. Live versus dead cells were either scored by a two-color fluorescence assay involving ethidium homodimer and calcein AM (c, d, $\mathbf{g}, \mathbf{h})$ or Hoechst 33258 staining $(\mathbf{a}, \mathbf{b}, \mathbf{e}, \mathbf{f})$. Similar results were obtained with v-Crk-expressing clone V15. Magnification is $20 \times$. 
In contrast to the effects of $\mathrm{v}$-Crk in NGF-deprived neuronal PC12 cells, v-Crk did not exert a survival benefit when naive undifferentiated PC12 cells were deprived of serum as a source of growth factors, as this condition led to comparable cell death to that of nontransfected PC12 cells (Figure $3 \mathrm{C}$ ). A reciprocal test of the role of NGF-mediated differentiation in predicting $v$-Crk's survival advantage is to examine a cell line which cannot differentiate with exogenous NGF. For these experiments, we isolated a mutant v-CrkPC12 cell line, termed NR-v-Crk, or 'NonResponder' v-Crk. NR-v-Crk PC12 cells were isolated by
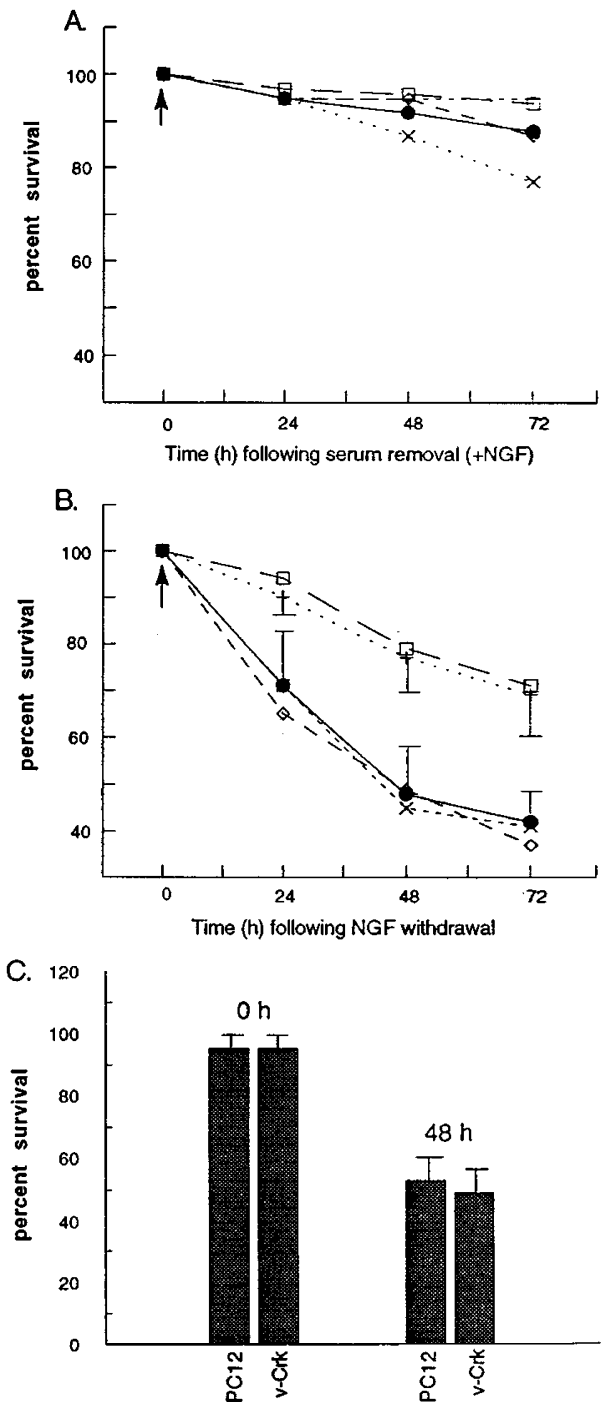

Figure 3 v-Crk promotes the survival of NGF-differentiated PC12 cells following NGF withdrawal. (a and b). Native PC12 (0), v-Crk-expressing PC12 clones V1 $(+)$ or V15 $(\square)$, R273N-v-Crk $(\diamond)$, and NR-V-Crk PC12 $(x)$ cells were maintained in $3 \%$ serum plus $50 \mathrm{ng} / \mathrm{ml} \mathrm{NGF}$ for 14 days and then placed in serum free media (indicated by the arrow) containing $50 \mathrm{ng} / \mathrm{ml} \mathrm{NGF} \mathrm{(A)} \mathrm{or}$ serum-free media without added growth factor (B) for up to $72 \mathrm{~h}$. Live versus dead cells were scored by the two-color fluorescence assay shown in Figure 2. Data show the mean \pm S.E. of at least six independent experiments. (c) native PC12 cells or V-CrkPC12 cells were grown in $3 \%$ serum without NGF for 1 week and then placed in serum free media for $48 \mathrm{~h}$. limiting dilution and clonal expression of V1 clones that no longer responded (via neurite outgrowth) to EGF, NGF, or bFGF, indicating a general defect in growth factor dependent neurite outgrowth (Figure 4). When examined for v-Crk levels by anti-Gag Western blotting, four out of the six clones analyzed continued to express $\mathrm{v}$-Crk at levels equivalent to the parental v-Crk PC12 cell lines (Figure 4A)

A. Isolation of Non-responsive (NR) v-CrkPC12 Cells.

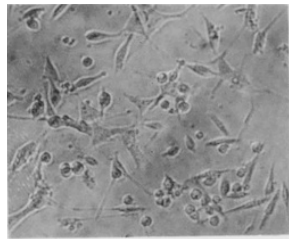

Morphology of v-CrkPC12 cells (4 months in $50 \mathrm{ng} / \mathrm{ml} \mathrm{EGF)}$

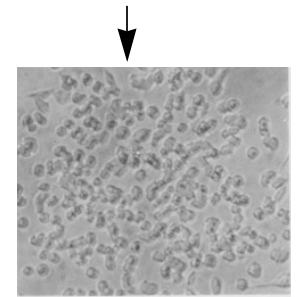

Limiting Dilution and Recovery of NR Clones $\downarrow$

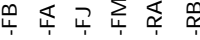
خै

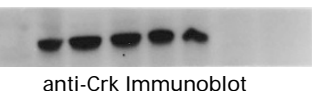

B

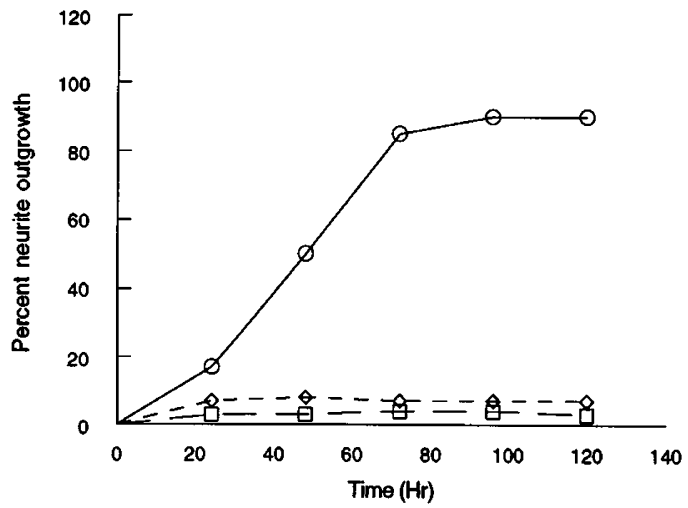

Figure 4 Isolation of Non-responder (NR) v-Crk PC12 cells. (A) v-Crk expressing PC12 clone $\mathrm{V} 1$, maintained for approximately 4 months in $3 \%$ serum plus $50 \mathrm{ng} / \mathrm{ml} \mathrm{EGF}$, was trypsinized and diluted to approximately ten cells per $10 \mathrm{~cm}$ dish. Cells were then expanded as clonal lines and individual clones not responding to EGF were isolated (middle panel). $40 \mu \mathrm{g}$ of detergent lysate was Western blotted with anti-Gag antibody (monoclonal antibody 3C2) to monitor $\mathrm{v}$-Crk expression. The clone numbers are indicated on the top of the gel. (B) NR-v-Crk cells do not differentiate with EGF or NGF. Wild-type vCrkPC12 cells (V1) treated with EGF $(O)$ or clone NRV1-FA treated with $50 \mathrm{ng} /$ $\mathrm{ml} \mathrm{EGF}(\square)$ or $50 \mathrm{ng} / \mathrm{ml} \mathrm{NGF}(\diamond)$ for up to $120 \mathrm{~h}$ and were scored for neurite outgrowth as in Figure 1. Other NR-v-Crk clones gave the same results. 
and therefore were chosen for further studies. Moreover, the $\mathrm{V}$-Crk in these cells stably complexed with tyrosine phosphorylated EGF Receptor, $\mathrm{p} 130^{\text {cas }}$ and paxillin suggesting that $v$-Crk was wild-type in these cells (data not shown). Although NR-v-Crk cells do not differentiate in response to NGF, they do maintain viability under serum free conditions in the presence of $50 \mathrm{ng} / \mathrm{ml}$ NGF (Figure $3 \mathrm{~A})$. Thus, these cells represent a system where one can clearly dissociate survival and differentiative pathways. These latter characteristic distinguishes NR-v-Crk cells mechanistically from the PC12nnr5 cell mutants isolated by Greene and colleagues which are non-responsive to NGF due to lack of TrkA expression (Loeb and Greene, 1993). Importantly, NR-v-Crk cells did not retain the survival promoting action of $\mathrm{v}$-Crk upon NGF deprivation (Figure 3B). Taken together, the results in Figure 3 and 4 demonstrate that $\mathrm{PC} 12$ cells expressing $\mathrm{v}$-Crk require prior differentiation by NGF in order for $\mathrm{v}$-Crk to exert a cytoprotective effect.

Given the fact that $\mathrm{v}$-Crk potentiates TrkA signaling (Hempstead et al, 1994), and delays apoptosis only in cells with a neuronal phenotype, we hypothesized that over-

\section{A.}

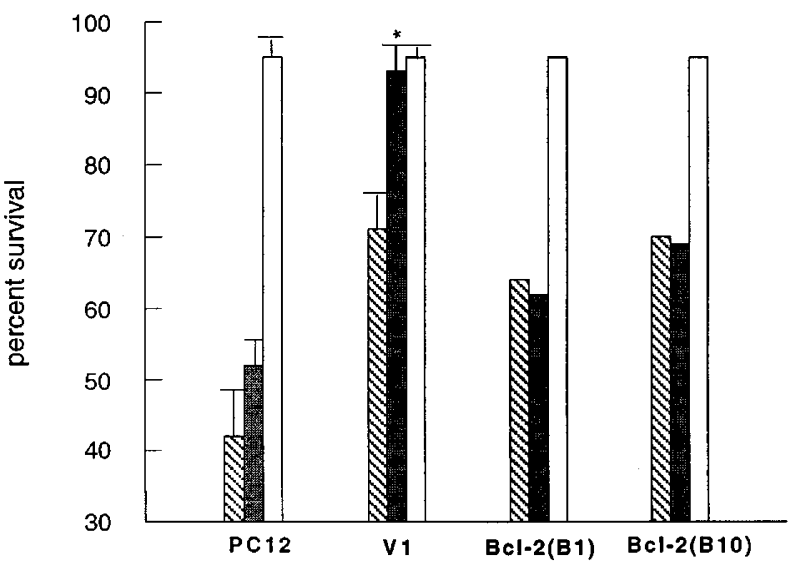

B.

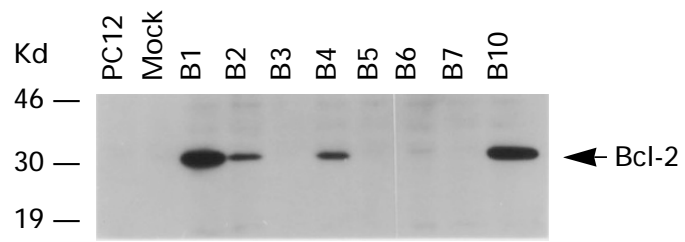

Figure 5 EGF replaces NGF as a neurotrophic factor in v-Crk-expressing PC12 cells but not Bcl-2-expressing PC12 cells. Native PC12 cells or PC12 cells expressing $\mathrm{V}$-Crk (clone $\mathrm{V} 1$ ), human $\mathrm{Bcl}-2$ (clones $\mathrm{B} 1$ and $\mathrm{B} 10$ ) or TrkA

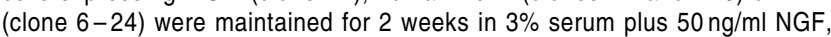
after which serum and NGF were washed off, and replaced with $0 \%$ serum in the absence of growth factor (hashed symbol), $0 \%$ serum containing $50 \mathrm{ng} / \mathrm{ml}$ EGF (shaded symbol), or $50 \mathrm{ng} / \mathrm{ml} \mathrm{NGF} \mathrm{(open} \mathrm{symbol).} \mathrm{The} \mathrm{error} \mathrm{bars} \mathrm{in} \mathrm{PC12}$ versus $\mathrm{V}$-CrkPC12 cells denotes average \pm standard error of four independent experiments. (B) $50 \mu \mathrm{g}$ of total lysate from Human Bcl-2 transfected PC12 cell lines was Western blotted with an antibody specific for human $\mathrm{Bcl}-2$ to indicate protein expression. The position of molecular weight standards (in kD) are indicated on the left and Bcl-2's migration is indicated on the right. expression of TrkA itself may sustain viability in cell-free conditions. To address this question, we assessed survival in Trk 6-24 PC12 cells that exhibit 20-fold overexpression of the TrkA receptor (Hempstead et al, 1993). Figure 6B shows Hoechst staining of nuclei $48 \mathrm{~h}$ after NGF withdrawal in native $\mathrm{PC} 12$ cells and TrkA-expressing PC12 cells. We found no evidence of apoptotic condensed chromatin in any TrkA PC12 cells, by contrast to what we observed with native cells. Moreover, when cells were stained with calcein AM, over $95 \%$ of the Trk $6-24$ cells survived following $72 \mathrm{~h}$ of NGF deprivation (Figure 6A). Hence, overexpression of Trk A in PC12 cells appears to confer growth factor independence in PC12 cells.

\section{EGF is a survival factor in v-Crk-expressing PC12 cells}

Our previous findings demonstrated that EGF, a mitogenic growth factor in native PC12 cells, causes neurite outgrowth in v-Crk-expressing PC12 cells (Hempstead et al, 1994). To determine whether EGF could also rescue cells from apoptosis during NGF-deprivation, we replaced NGF with an identical concentration of EGF in long-term NGF-treated cells to assess its survival potential (Figure 5A). In two phenotypically differentiated v-Crk expressing cell lines, V1and V15-PC12 cells, EGF was identical to NGF in acting as a neurotrophin; For example, $72 \mathrm{~h}$ after serum withdrawal, 93\% of $\mathrm{V} 1-\mathrm{PC} 12$ cells were rescued in EGF alone, $94 \%$ in NGF alone, as compared to $71 \%$ in the absence of growth factor (Figure $5 \mathrm{~A}$ ). In fact, over $90 \%$ of the $\mathrm{v}$-CrkPC12 cells were alive after 7 days in serum free media with EGF alone, while less than $10 \%$ survived in the absence of growth factor (not shown). EGF did not significantly augment survival in native PC12 cells, corroborating results by Greene et al (1991). To show that these effects were specific to $\mathrm{v}$-Crk, we also stably expressed $\mathrm{Bcl}-2$ in $\mathrm{PC} 12$ cells since $\mathrm{Bcl}-2$ has been shown to confer resistance to apoptosis when overexpressed in PC12 cells (Mah et al, 1993) or SCG neurons (Garcia et al, 1992). Two independent $\mathrm{PC} 12$ clones, $\mathrm{B} 1$ and $\mathrm{B} 10$, showing highest levels of Bcl-2 expression (Figure $5 \mathrm{~B}$ ), were chosen for the viability assays. Consistent with previous findings (Mah et al, 1993), Bcl-2 partially protected differentiated PC12 cells from apoptosis in the absence of NGF. The degree of protection during NGF withdrawal in the v-Crk-expressing PC12 cells and $\mathrm{Bcl}-2$-overexpressing $\mathrm{PC} 12$ cells were qualitatively similar, wherein approximately $70 \%$ of the cells in clone B10 were viable $72 \mathrm{~h}$ after NGF withdrawal (Figure 5A). Importantly, however, EGF replacement did not further enhance the survival benefits of $\mathrm{Bcl}-2$ during NGF deprivation (Figure $5 \mathrm{~A}$ ) suggesting that $\mathrm{v}-\mathrm{Crk}$ and $\mathrm{Bcl}-2$ may operate through separate survival pathways.

Finally, to underscore that the effects of v-Crk were contingent on tyrosine kinase signaling, we utilized an $\mathrm{SH} 2$ inactive v-Crk mutant cell line R273N-v-Crk. R273N-v-Crk cannot bind phosphotyrosine-containing proteins and are slower than native PC12 cells in making neurites in response to $50 \mathrm{ng} / \mathrm{ml}$ of NGF (Teng et al, 1995). R273Nv-Crk PC12 cells are also susceptible to apoptosis in the absence of NGF and died at comparable rates to native PC12 cells following serum and NGF removal (Figure 3B). 

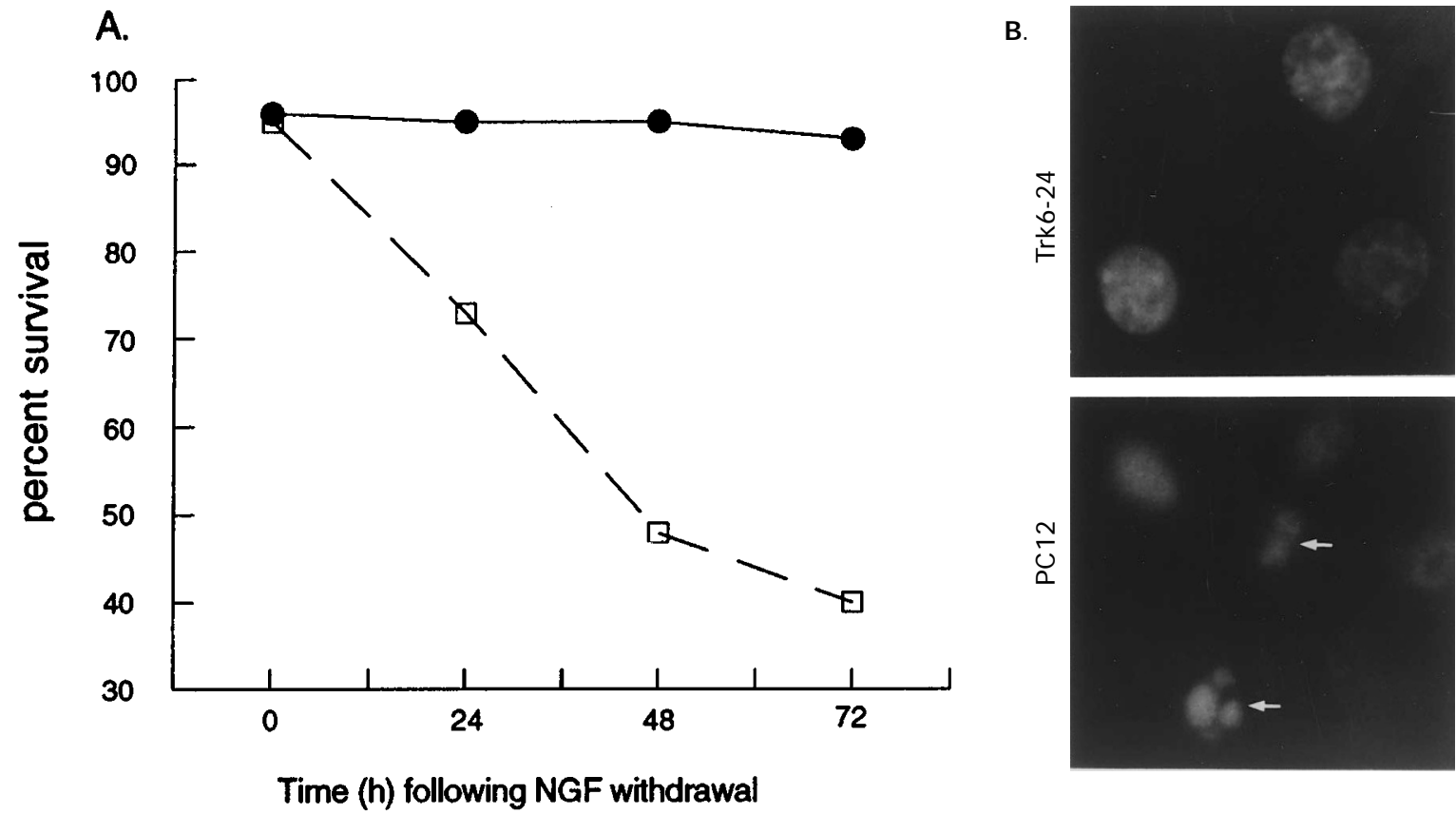

Figure 6 Overexpression of TrkA suppress apoptosis. TrkA overexpressing cells (clone $6-24)(\mathbf{)})$ or native PC12 cells ( $\square$ ) were maintained as in Figure 2 , and then transferred to NGF-depleted media for up to $72 \mathrm{~h}$. (A) ethidium homodimer and calcein AM were utilized to determine the percentages of dead cells during NGF withdrawal. (B) the cells were grown on collagen-coated glass coverslips followed by NGF withdrawal for $48 \mathrm{~h}$. Cells were DAPI stained as in Figure 2. The appearance of condensed chromatin in PC12 cells are indicated by the arrows.

Furthermore, EGF addition did not rescue R273N-v-Crk cells from apoptosis (data not shown). These data corroborate the above findings and suggest that PC12 survival advantage relies on intact signaling from receptor tyrosine kinases and may be related to the properties of $\mathrm{v}$ Crk necessary for neurite outgrowth.

\section{v-Crk and Trk A delay apoptosis in the absence of cell cycle arrest}

After several days of NGF treatment, PC12 cell proliferation typically ceases and differentiation occurs (Rudkin et al, 1989). Previous studies with G1-arrested PC12 cells or postmitotic sympathetic neurons support a hypothesis that postmitotic neurons and neuronal PC12 cells undergo apoptosis under NGF withdrawal by re-entering the cell cycle, an event referred to as a 'defective cell cycle' (Rubin et al, 1993). When PC12 cells were cultured for 11 days in $50 \mathrm{ng} / \mathrm{ml} \mathrm{NGF}$, NGF exerted an antiproliferative effect as evident from the lower number of total cells in $3 \%$ serum containing NGF as compared to $3 \%$ serum alone (Figure $7 a$ ). In contrast, v-Crk, but not mutant R273N-v-Crk, and NR-v-Crk cells increased in number upon NGF addition consistent with the mitogenic effects of wild type v-Crk. Trk 6-24 cells also proliferated in response to long-term NGF treatment. It is especially intriguing that greater than $90 \%$ of Trk $6-24$ and vCrk PC12 cells had processes of more than two cell bodies in diameter upon NGF treatment (data not shown). This suggests that significant crosstalk exists between differentiative and proliferative pathways in these cell lines.
The results shown in Figure 7 suggest that v-CrkPC12 cells may have failed to arrest in $\mathrm{G} 1$ phase relative to their native PC12 counterparts in the events leading up to NGF withdrawal. To probe further into the relationship between cell cycle progession and apoptosis, we analyzed cell cycle parameters by (i) FACS using propidium iodide for DNA content (Table 1), and (ii) cdk2 activity (a cyclin-dependent kinase required at the G1/S transition) (Figure $7 \mathrm{~b}$ ) following NGF withdrawal. For the flow cytometry, cells were grown in media with $3 \%$ serum and $50 \mathrm{ng} / \mathrm{ml}$ of NGF for 14 days and then placed in one of four conditions: (i) $3 \%$ serum+NGF for an additional $24 \mathrm{~h}$; (ii) $0 \%$ serum + $50 \mathrm{ng} /$ ml NGF for $24 \mathrm{~h}$; (iii) $0 \%$ serum and no NGF for $12 \mathrm{~h}$ or (iv) $0 \%$ serum and no NGF for $24 \mathrm{~h}$. Several points are noteworthy from these data. First, congruent with the aforementioned effects of v-Crk on cell growth, v-Crk and NR-v-Crk PC12 cells consistently had a higher percentage of cells in S phase compared to the native PC12 cells (Table 1). For example, $24 \mathrm{~h}$ after NGF removal, v-CrkPC12 cells were $22 \%$ in S phase, compared to $15 \%$ in native cells. As expected, NR-v-Crk cells, which are the most proliferative (Figure $7 \mathrm{a}$ ), had the greatest percentage of cells in S-phase, and this steadily increases through $24 \mathrm{~h}$ of NGF withdrawal. It is interesting that NR-v-Crk cells appear to have a progressive G2/M block at 12 and $24 \mathrm{~h}$ in growth factor free conditions suggesting that they may undergo apoptosis during S-phase. Second, Trk6-24 cells had a high percentage of cells in G2/M. These cells do not appear to be growth arrested at G2/M since there was no diminution of cells in $S$ phase (Table 1). Finally, with the 
Table 1 FACS analysis of DNA content

\begin{tabular}{llll}
\hline Cell & \%G & $\% \mathbf{S}$ & $\% \mathbf{G}_{\mathbf{2}} / \mathbf{M}$ \\
\hline PC12 & & & \\
3\%+NGF & 73 & 13 & 14 \\
0\%+NGF & 70 & 14 & 16 \\
0\%x 24 h & 75 & 15 & 10 \\
V15-PC12 & & & \\
3\%+NGF & 64 & 21 & 15 \\
0\%+NGF & 66 & 23 & 11 \\
0\%x 12 h & 72 & 15 & 14 \\
0\%x 24 h & 69 & 22 & 9 \\
NRV1-C & & & \\
3\%+NGF & 66 & 29 & 5 \\
0\%+NGF & 54 & 37 & 4 \\
0\%x 12 h & 49 & 52 & 1 \\
0\%x 24 h & 47 & 16 & \\
Trk6-24 & & 14 & 24 \\
3\%+NGF & 60 & 11 & 29 \\
0\%+NGF & 60 & 13 & 29 \\
0\%x 12 h & 60 & 58 &
\end{tabular}

Cells were treated as in Figure 2 and then placed in one of four conditions; (i) cultured in 3\% serum plus NGF for an additional $24 \mathrm{~h}$ (ii) transferred to $0 \%$ serum plus NGF for $24 \mathrm{~h}$, or transferred to $0 \%$ serum without NGF for (iii) $12 \mathrm{~h}$ or (iv) $24 \mathrm{~h}$. Cells were harvested and stained with propidium iodide, and the nuclei were isolated and analyzed by flow cytometry. Results are repesentative of several independent experiments. The data are summarized from the DNA frequency distribution histograms. $G_{0} / G_{1}, S$, and $G_{2} / M$ cell populations are indicated
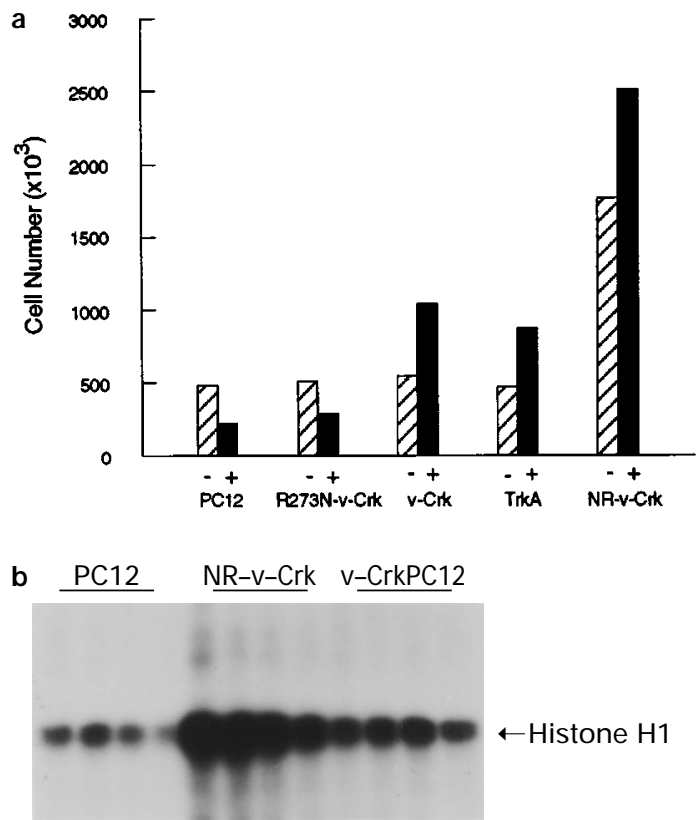

$\begin{array}{llllllllllll}1 & 2 & 3 & 4 & 1 & 2 & 3 & 4 & 1 & 2 & 3 & 4\end{array}$

I.P with anti-cdk2/Kinase assay

Figure 7 Analysis of cell proliferation in PC12 cells. (a) Cell doubling time. Native PC12, R273N-v-Crk, v-Crk, TrkA, or NR-v-Crk PC12 cells were trypsinized and 10,000 cells seeded subconfluently in either $3 \%$ serum (hashed symbol) or $3 \%$ serum containing $50 \mathrm{ng} / \mathrm{ml} \mathrm{NGF} \mathrm{(shaded} \mathrm{symbol)} \mathrm{for} 11$ days. The wells were counted on a hematocytometer and data represent the average of triplicate wells. (b) Cdk2 activity. PC12, NR-v-Crk, or v-Crk PC12 cells maintained in $3 \%$ serum plus NGF for 14 days (lane 1 ) were deprived of serum and growth factor for 4,8 or $12 \mathrm{~h}$ (lanes $2-4$, respectively). For each condition, $400 \mu \mathrm{g}$ of protein lysate was immunoprecipitated with anti-cdk2 antibody and assayed for kinase activity with $5 \mu \mathrm{g}$ of histone $\mathrm{H} 1$ as a substrate. The migration of the phosphorylated substrate is indicated by the arrow. exception of NR-v-Crk cells, there did not appear to be any major fluctuation in cell cycle distribution within each line as a result of NGF withdrawal.

Conclusions from FACS are corroborated from the results of cdk2 kinase activity (Figure 7b). Native PC12 cells, which are known to down regulate kinase activity after exposure to NGF (Buchkovich and Ziff, 1994), show further diminution in activity after serum and NGF withdrawal. Most evident, however, is that the most striking differences in cdk2 activity occur between different cell lines. V-CrkPC12 cells had about twice the level of cdk2 activity per mg of cellular protein as native PC12 cells and, as expected, NR-v-Crk had dramatically higher cdk2 activity in all conditions. Similar to native PC12 cells, both NR-vCrk cells and v-CrkPC12 cells exhibited modest diminution in cdk2 activity after serum or NGF withdrawal.

\section{Cell death in PC12 cells is associated with activation of JNK and MAP kinase}

Recently, it has been reported that sustained c-Jun N-terminal kinase (JNK) activity and suppressed Erk/MAP kinase activity accompany PC12 apoptosis during NGF withdrawal (Xia et al, 1995). Taken together with our findings that v-Crk causes sustained activation of MAP kinase immediately after NGF stimulation (Teng et al, 1995), we examined the activation status of MAP kinase and JNK in Trk6-24, v-Crk, and native PC12 cells (Figure 8). Consistent with the results of Greenberg and colleagues, we observed a significant increase in JNK activity $6-8 \mathrm{~h}$ after NGF withdrawal in native PC12 cells. On the other hand, JNK activity was abated during NGF withdrawal in the Trk6-24 and v-Crk cells. Moreover, native PC12 cells and the R273N-v-Crk PC12 cells also had a significant increase in MAP kinase activity $6-$ $8 \mathrm{~h}$ following NGF withdrawal while Trk6-24 and v-Crk PC12 cells did not show augmentation in MAP kinase activity. Thus, neuronal cell lines prone to apoptosis manifest an augmentation in MAP kinase and Jun Kinase activity within $8 \mathrm{~h}$ of growth factor removal, while cell lines resistant to apoptosis failed to demonstrate kinase activation (Table 2).

\section{Discussion}

Both naive and NGF-differentiated (neuronal) PC12 cells undergo apopotic cell death upon removal of serum and NGF, respectively (Lindenboim et al, 1995; Mesner et al, 1992). These properties of PC12 cells have therefore been proposed to mimic the dependence of mitotic and postmitotic neurons on growth factors in the developing nervous system. In our previous work, we established a model system to study NGF dependent neuritogenesis by expressing the $\mathrm{SH} 2 / \mathrm{SH}_{3}-$ containing adapter protein v-Crk in PC12 cells (Hempstead et al, 1994; Teng et al, 1995). The present study documents the ability of $\mathrm{v}$-Crk to delay apoptotic cell death in NGFdeprived neuronal PC12 cells. This capacity of $\mathrm{v}$-Crk requires prior NGF priming since serum withdrawal on naive undifferentiated v-Crk-expressing PC12 cells did not yield a survival advantage over native PC12 cells. These data point to the importance of SH2/SH3-containing adapter proteins which can act on intracellular pathways of TrkA signaling and 
A. IP: erk $1 \& 2$

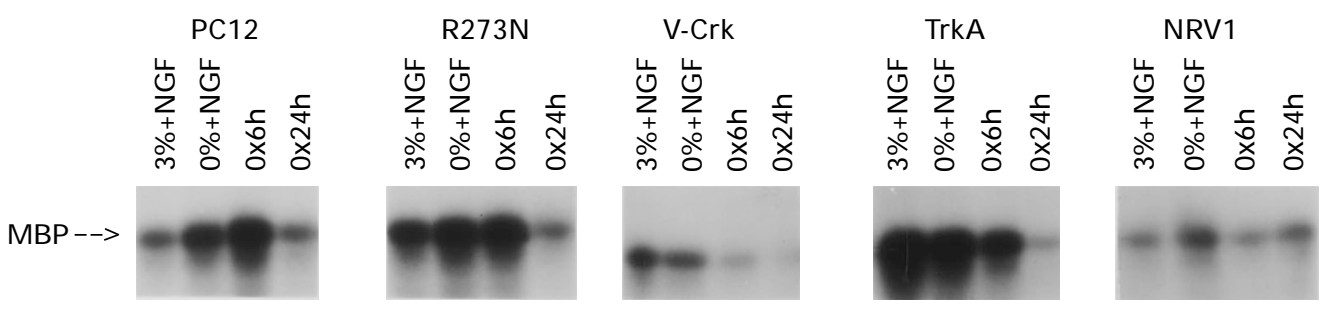

B. IP: J nk

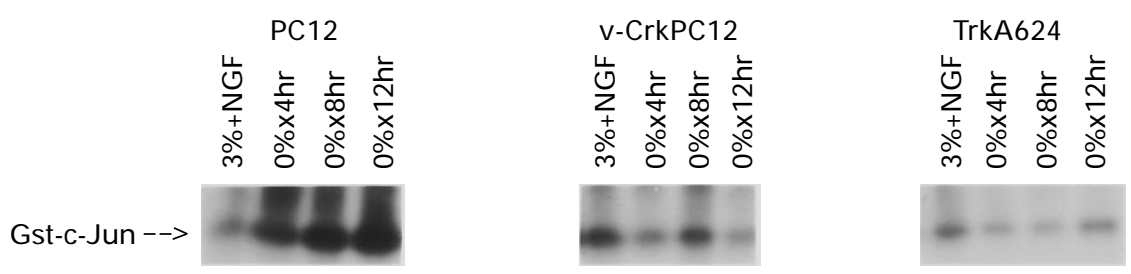

Figure 8 Activity of MAP Kinase and JNK during neuronal apoptosis. Native PC12 cells and the indicated transfectants were maintained in $3 \%$ serum plus 50 ng/ $\mathrm{ml}$ of NGF for 2 weeks (lane 1 in each grouping) and then placed in either of three conditions: $0 \%$ serum $+50 \mathrm{ng} / \mathrm{ml} \mathrm{NGF}$ for an additional $24 \mathrm{~h}$ (lane 2 ); $0 \%$ serum without NGF for $6 \mathrm{~h}$ (lane 3); or $0 \%$ serum without NGF for $24 \mathrm{~h}$ (lane 4). $200 \mu \mathrm{g}$ and $400 \mu \mathrm{g}$ of total protein lysate for each condition was immunoprecipitated with specific antibodies for MAP Kinase (a) and JNK, respectively (b). The immunoprecipitate was then assayed for kinase activity using MBP (a) or a GST fusion protein containing the first 79 amino acids of c-Jun (b) as substrates. The positions of the phosphorylated substrates are indicated on the left.

Table 2 Summary of cell lines utilized in this study. Relationships between kinetics of differentiation to NGF, S-phase response to NGF, and kinase activity and survival in absence of growth factor

\begin{tabular}{|c|c|c|c|c|}
\hline Cell line & $\begin{array}{l}\text { Kinetics of neurite } \\
\text { outgrowth (+) NGF }\end{array}$ & $\begin{array}{l}\text { Cell cycle response } \\
(+) \text { NGF }\end{array}$ & $\begin{array}{l}\text { JNK and MAPK activity } \\
(-) \text { NGF }\end{array}$ & $\begin{array}{c}\text { Survival } \\
\text { (-) NGF } 72 \mathrm{~h}\end{array}$ \\
\hline Native PC12 & + & $\mathrm{G}_{1}$ & increased & $40 \%$ \\
\hline R273N-v-crk & - & $\mathrm{G}_{1}$ & increased & $40 \%$ \\
\hline NR-v-crk & 0 & $S$ & no $\Delta$ & $35 \%$ \\
\hline v-crk-PC12 & ++ & $\mathrm{S}$ & decreased & $70 \%$ \\
\hline Trk 6-24 & +++ & $\mathrm{S}$ & decreased & $95 \%$ \\
\hline
\end{tabular}

For native PC12 cells and the indicated transfectants, the following parameters were summarized: (i) kinetics of differentiation to NGF (column 1); (ii) cell cycle response to NGF (column 2); (iii) activities of JNK and MAP kinase after NGF withdrawal (column 3) and (iv) survival in the absence of NGF (column 4). In column 1, ' + ' signals a baseline velocity of neurite outgrowth, '++' and '+++' represent progressive acceleration, ' - ' indicates a dominant negative effect, and ' 0 ' indicates a total lack of NGF-induced neurite outgrowth. In column 2, ' $\mathrm{G}_{1}$ ' indicates more cell cycle arrest and ' $\mathrm{S}$ ' indicates increased proliferation

transduce survival signals when calls are deprived of extracellular trophic support.

The ability of v-Crk to delay apoptosis specifically in growth factor-deprived neuronal PC12 cells, but not naive PC12 cells, suggests that v-Crk is an effector of the NGF signaling pathway and can act directly downstream to TrkA. This is not only supported by the fact that overexpression of TrkA completely renders cells NGF-independent for at least 5 days, as would be expected if TrkA were an upstream regulator of $\mathrm{v}$-Crk, but by several other experimental observations including: (i) v-Crk induces neurite outgrowth in cells treated with a subthreshold concentration of NGF (Figure 1; Hempstead et al, 1994) (ii) $\mathrm{v}$-Crk is tyrosine phosphorylated immediately following NGF stimulation (Hempstead et al, 1994) (iii) v-Crk augments NGF-induced GDP-GTP exchange on p2 $1^{\text {ras }}$, a known downstream effector of TrkA (Teng et al, 1995) and (iv) expression of a dominant negative v-Crk (R273N-vCrk), which carries a point mutation in the $\mathrm{SH} 2$ domain, impairs NGF-induced neurite outgrowth (Teng et al, 1995), and as shown here, does not suppress apoptosis like wildtype v-Crk. Therefore, it is likely that v-Crk, by virtue of its ability to modulate TrkA tyrosine kinase activity/signaling after NGF removal, maintains a threshold of trophic support necessary for immediate PC12 survival. However, the augmentation of tyrosine kinase activity need not be restricted to TrkA, since restimulation of the EGF Receptor in NGF-deprived $\mathrm{PC} 12$ cells with EGF completely compensated for TrkA and yielded long-term survival. The fact that tyrosine kinase inhibitors staurosporine and K252A can induce apoptosis further argue that modulation of tyrosine kinase signaling can have striking effects on cell survival (Bertrand et al, 1994). Similarly, agonists which act on TrkA, such as GM1 ganglioside, have also been shown to significantly delay apoptosis (Ferrari et al, 1995). Recently, it has been shown that overexpression of wildtype PDGF-Receptor, but not a mutant PDGF-Receptor lacking the Phosphatidylinositol-3' Kinase (PI3'-Kinase) 
binding site, confers PC12 survival, implicating a role for PI3-Kinase as a downstream effector of receptor kinases during protection from apoptosis (Yao and Cooper, 1995),

One hypothesis is that the pathways which augment differentiation via $\mathrm{v}$-Crk may also play a role in enhancing v-Crk-mediated survival. This is supported by several lines of reasoning (Table 2). First, neuronal cell lines with accelerated kinetics of differentiation, such as Trk A or vCrk-PC12 cells, also have enhanced survival curves in the absence of growth factor. In contrast, cells which are impaired in NGF-induced differentiation, such as R273N-vCrk and NR-v-Crk PC12 cells, did not show any protection from neurotrophin-deprived apoptosis. Finally, EGF, which completely rescues $\mathrm{v}$-CrkPC12 cells from apoptosis due to NGF deprivation, also promotes neurite outgrowth uniquely in v-CrkPC12 cells (Hempstead et al, 1994). Interestingly, long-term surviving Bcl-2 expressing cells maintained in the absence of NGF undergo neuronal differentiation suggesting a close mimicry between neuronal survival and neuronal differentiation (Sato et al, 1994). However, while NGF-differentiated PC12 cells expressing human Bcl-2 had delayed apoptosis comparable to $\mathrm{v}$-Crk in the complete absence of growth factor, addition of EGF to these cultures did not further rescue them from apoptosis. Thus, we have provided evidence that one can predict the comparative viability after NGF withdrawal in PC12 transfectants based upon knowledge of their kinetics of differentiation to NGF.

Presently, we do not know the molecular mechanisms by which v-Crk potentiates NGF's effects on cell survival. Immediately following NGF or EGF addition to v-Crk-PC12 cells, v-Crk binds to the tyrosine phosphorylated TrkA Receptor (Hempstead et al, 1994) or EGF Receptor, respectively (Teng et al, 1995) and causes a sustained activation of $\mathrm{p} 21^{\text {ras }}$, which apparently plays a role in potentiating differentiation (Teng et al, 1995). While activation of the Ras/Raf/MAP Kinase pathway is critical for the differentiation of PC12 cells (Kaplan and Stephens, 1994), the role of Ras/MAP kinase during apoptosis is a matter of controversy. While expression of dominant negative RasN17 does not prevent the killing of naive PC12 cells during serum deprivation (Yao and Cooper, 1995), RasN17 expressed from an inducible dexamethasone-inducible promoter prevented neuronal PC12 cell apoptosis after NGF deprivation, presumably by blocking cell cycle progression (Ferrari and Greene, 1994). In contrast, induction of apoptosis in NGF-differentiated PC12 cells could be markedly suppressed by expression of a constitutively activated MKK1, a dual specificity kinase that specifically phosphorylates and activates Erk/MAP kinase (Xia et al, 1995). In the experiments described here, MAP Kinase had diminished activity during NGF withdrawal in TrkA and v-Crk-expressing PC12 cells, but increased activity in native $\mathrm{PC} 12$ cells that are more prone to apoptosis. These data suggest that MAP Kinase activity may be of lessor importance for v-Crk and TrkA induced survival than for their differentiation. It is certainly possible that both Ras-dependent and Ras-independent apoptosis occurs (Borasio et al, 1993) depending upon cellular factors such as the initial cell cycle distribution. The MEKK and JNK pathways also appears to be critical components of the apoptotic machineries (Johnson et al, 1996; Xia et al, 1995). NGF withdrawal leads to sustained increases in JNK activity and dominant-interfering forms of the enzyme (Xia et al, 1995) or its substrate c-Jun (Ham et al, 1995) leads to abrogation of growth factor requirements in PC12 cells and sympathetic neurons, respectively. Consistent with these data, we have shown that lines relatively resistant to apoptosis manifest decreases in JNK activity after NGF removal. Thus, v-Crk or TrkA might impinge on downstream serine/threonine kinases such as MAP Kinase or JNK1, creating a cellular milieu impervious to growth factor withdrawal.

A second hypothesis is that TrkA and Crk affect cell cycle progression in such a way that NGF removal is not accompanied by programmed death. Native PC12 cells continue to proliferate for 4 to 5 days following NGF stimulation prior to their $G_{1}$ arrest and subsequent differentiation. An emerging model, mentioned previously, that may partially explain the mechanism of apoptosis in postmitotic neurons following withdrawal of trophic support postulates that cells attempt an abortive transversal of cell cycle progression (Rubin et al, 1993). Based upon these considerations, one might predict that $\mathrm{v}$-Crk or TrkA, like N17Ras (Ferrari and Greene, 1994) or p16 ${ }^{\mathrm{INK}}$ (an inhibitor of cyclin D-dependent kinases) (Kranenburg et al, 1996), would protect $\mathrm{PC} 12$ cells by promoting growth arrest during long-term NGF treatment. However, we observed the opposite, whereby neuronal TrkA or v-Crk PC12 cells, despite appearing phenotypically differentiated, appear to by-pass normal $\mathrm{G}_{1}$ checkpoints and maintain more robust cell cycle activity after 14 days in continuous NGF as measured by cell doubling analysis, flow cytometry, and cdk2 activity.

Because v-Crk-PC12 cells appear to be more mitogenically active than native PC12 cells after long-term NGF treatment in low serum, the relationships between cessation or cell proliferation, differentiation, and apoptosis may be more accurately viewed in terms of the cell cycle hypothesis for proliferating neuroblasts. In this model, mitogenic neuroblasts would retain cell cycle proteins and hence do not require de novo RNA synthesis prior to apoptosis (Lindenboim et al, 1995). Therefore, v-Crk may activate signaling events which support PC12 cells through subsequent cell cycle progression upon NGF and serum withdrawal, thereby achieving a delay in apoptosis. We should point out that there was no evidence of dramatic perturbations in cell cycle distribution in v-CrkPC12 cells within $24 \mathrm{~h}$ following a switch to growth factor free conditions, suggesting that these parameters are not modulated as a means of resistance to an apoptotic stimulus. However, we must reconcile the fact that v-Crk does not have the capacity to spare undifferentiated fully mitotic PC12 cells nor NR-v-Crk PC12 cells from apoptosis during serum removal and, as noted above, molecules related to $v$-Crk's role in differentiation likely play a role in exerting v-Crk's cytoprotective effects. Relevantly, apoptosis in serum-deprived mitotic PC12 cells is not restricted to the $G_{0}-G_{1}$ phase of the cell cycle, and death can occur at $S$ and $G_{2} / M$ phase (Lindenboim et al, 1995). However, since v-CrkPC12 cells are not initially $G_{1}$ arrested upon 
differentiation, v-Crk's affects on apoptosis need not be restricted to one phase of the cell cycle and thus modulation of the cell cycle parameters may be less important than v-Crk's effects on signaling molecules. Of course, v-Crk expression or TrkA overexpression might foster cellular viability through means other than manipulation of cell cycle dynamics, differentiative pathways, or kinase pathways. Among other possibilities, v-Crk might lead to an inhibition of interleukin- $1 \beta$-converting enzyme (ICE) or CPP32 activity, or up regulation of anti-apoptotic genes, such as Bcl-2 or Bcl-x (Nicholson et al, 1995; Gonzalex-Garcia et al, 1995; Motoyama et al, 1995).

The present study was undertaken to describe the role of $\mathrm{v}$-Crk in modulating neurotrophic activity in neuronal PC12 cells. We have found a novel function for v-Crk and propose that adapter proteins may provide an important mechanism to enhance neurotrophin-dependent tyrosine kinase activity to influence survival and differentiation in the developing nervous system. Moreover, the findings that EGF can replace NGF as a neurotrophic factor in differentiated $\mathrm{v}$-CrkPC12 cells may have broader implications concerning the role of EGF and the EGF Receptor in nonproliferating neurons in the nervous system. EGF can act as a local survival and differentiation factor in certain cerebellar primary neurons (Tucker et al, 1994) and the EGF Receptor has been detected in adult neurons from the cerebellum, cortex, and hippocampus (Gomez-Pinilla et al, 1988). Interestingly, our results here suggest that in the context of v-Crk, EGF Receptors and TrkA Receptors seem to perform identical functions with respect to neurotrophism. Therefore, an attractive hypothesis suggests that adaptor proteins, like Crk, which act stoichiometrically to strengthen receptor tyrosine kinases, may control the signaling events leading to mitosis, differentiation and survival. Future studies examining the role of Crk and other adapters as regulators of apoptosis in vivo should further our understanding of signal transduction.

\section{Materials and Methods}

\section{Cell culture and transfection}

Rat pheochromocytoma cells (PC12) were a kind gift from Dr. David Kaplan (NCl-Frederick) and maintained in Dulbecco's modified Eagle's medium (DMEM) supplemented with $7 \%$ heat inactivated calf serum and $3.5 \%$ heat inactivated horse serum at $37^{\circ} \mathrm{C}$ in a humidified atmosphere of $5 \% \quad \mathrm{CO}_{2}$. Stable $\mathrm{PC} 12$ transfectants expressing v-Crk (Hempstead, 1994), R273N-v-Crk (Teng et al, 1995), and TrkA (Hempstead et al, 1992) were generated as described. Parental cells plated on a rat tail collagen coated $100 \mathrm{~mm}$ plate were also transfected with $20 \mu \mathrm{g}$ of pSFFV $b c /-2 \mathrm{nl}$ (obtained from Dr. Stanley Korsmeyer, Washington University) along with $20 \mu \mathrm{g}$ of salmon sperm DNA, and $50 \mu \mathrm{l}$ of lipofectamine (diluted $1: 7$ from the original stock) (Gibco). The plasmid pSFFV $b c l-2 n l$ contains a spleen focus-forming virus long terminal repeat driving the constitutive expression of a human $b c /-2$ complementary DNA. Cells were selected in $\mathrm{G} 418(500 \mu \mathrm{g} / \mathrm{ml})$, subcloned and expanded. Nonresponding v-Crk PC12 cells (NR-v-Crk PC12) were isolated through limiting dilution from $\mathrm{V}$-Crk $\mathrm{PC} 12$ cells maintained for approximately 4 months in DMEM supplemented with $2 \%$ calf serum, $1 \%$ horse serum, and $50 \mathrm{ng} / \mathrm{ml}$ of EGF. Cells were diluted into a 96-well rat tail collagen coated plate at a density of approximately $1-10$ cells/well, and cultured in $10 \%$ serum $(6.5 \%$ calf, $3.5 \%$ horse) DMEM until individual colonies could be recovered and expanded. Those lines which did not differentiate in the presence of EGF were subcloned and expanded. In all cell cultures, the media was replaced every $48 \mathrm{~h}$. As indicated in the text, media was supplemented with $50 \mathrm{ng} / \mathrm{ml}$ of either receptor grade mouse 2.5S NGF (Bioproducts for Science) or receptor grade mouse EGF (Bioproducts for Science). Prior to placement in growth factor-free media, cells were gently washed twice in large volumes of unsupplemented DMEM while attached to the collagen-coated plate.

\section{Viability/death assays}

Percentages of live and dead cells were obtained through a two-color fluorescence assay (Molecular Probes, Eugene, OR) that measures (i) intracellular esterase activity (a sign of viability) via the enzymatic conversion of non fluorescent cell-permeant calcein $\mathrm{AM}$ to the intensely green calcein; and (ii) plasma membrane integrity by means of ethidium homodimer which enters damaged membranes and undergoes a $40 \times$ enhancement of red fluorescence upon binding to nucleic acids. The assay was done on a 24 well rat tail collagen coated plate (Bioproducts for Science). For each condition, triplicate wells of adherent cells were gently washed in Phosphate Buffered Saline (PBS) supplemented with $9 \mathrm{mM} \mathrm{CaCl} 2$ and $5 \mathrm{mM} \mathrm{MgCl}_{2}$ $\left(\mathrm{PBS}^{+}\right)$. Cells were then incubated at $37^{\circ} \mathrm{C}$ for $20 \mathrm{~min}$ in $250 \mu \mathrm{l}$ of $2 \mathrm{mM}$ calcein $\mathrm{AM}$ and $4 \mathrm{mM}$ ethidium homodimer in $\mathrm{PBS}^{+}$. After aspiration of the solutions, percentages of live and dead cells were obtained by counting approximately 200 cells/well from several random fields using a conventional $485 \mathrm{~nm}$ fluorescein excitation filter. For Hoechst staining of chromatin, cells were differentiated on Poly-D-Lysine $12 \mathrm{~mm}$ coverslips (Collaborative Biomedical \#40425), after which cells were fixed with $3 \%$ paraformaldehyde, washed twice with PBS, and stained for $5 \mathrm{~min}$ at room temperature with an $8 \mu \mathrm{g} / \mathrm{ml}$ solution of Hoechst 33258 (Sigma) in PBS. After a final wash, DAPI auto fluorescence was measured using a $365 \mathrm{~nm}$ Excitation light source with a BA420 Barrier filter and photographed on a Nikon microscope.

\section{Immunoprecipitation, Western blotting and kinase assays}

For Western immunoblot analysis, cells were lysed in RIPA buffer (10 mM Tris HCl, $5 \mathrm{mM}$ EDTA, $150 \mathrm{mM} \mathrm{NaCl}, 10 \%$ glycerol, 1\% Triton $\mathrm{X}-100,1 \%$ Deoxycholic acid and $0.1 \%$ SDS) containing $1 \mathrm{mM}$ sodium vanadate, $1 \mathrm{mM}$ phenylmethylsulfonyl fluoride (PMSF), $1 \%$ aprotinin, and $100 \mu \mathrm{M}$ molybdate. Equivalent concentrations of protein, as measured by Bio-Rad Protein Assay using bovine serum albumin (BSA) as a standard, were resolved by sodium dodecyl sulfatepolyacrylamide gel electrophoresis (SDS-PAGE) and transferred to Immobilon-P (Millipore). The membrane was blocked in Tris-Buffered Saline (TBS) containing $1 \%$ BSA and then incubated with the indicated primary antibody for approximately $3 \mathrm{~h}$ at room temperature. Blots were washed with TBS containing $0.5 \%$ Tween 20 (TBS-T), incubated with peroxidase-conjugated secondary antibody, and washed again with TBS-T. All blots were developed by using the Renaissance Enhanced Chemiluminescence system (Dupont). Antibodies against Crk or Gag were used as previously described (Teng et al, 1995) while mouse monoclonal anti-human Bcl-2 antisera was obtained from DAKO.

For immunoprecipitations followed by kinase assays, cells were lysed in nonionic lysis buffer (20 mM HEPES, $150 \mathrm{mM} \mathrm{NaCl}, 10 \%$ 
glycerol) containing 1.0\% Triton X-100 (HNTG buffer). $200 \mu \mathrm{g}$ of protein from each lysate was immunoprecipitated with one of the following antibodies conjugated to Protein A sepharose beads: $15 \mu$ of monoclonal antibody of cdk2 (Santa Cruz), $3 \mu \mathrm{l}$ of a 1:1 mix of rabbit polyclonal antibodies to Erk 1 and Erk2 (sc-163, Santa Cruz), or $3 \mu \mathrm{l}$ of a monoclonal antibody to JNK1 (Pharmingen). After being washed five times with HNTG buffer adjusted to $0.1 \%$ Triton X-100, the beads were resuspended in $50 \mu \mathrm{l}$ of wash buffer containing $5 \mu \mathrm{Ci}$ of ${ }^{32} \mathrm{P}$. ATP, $5 \mu \mathrm{M}$ cold ATP, $10 \mathrm{mM} \mathrm{MnCl}_{2}$, and $5 \mu \mathrm{g}$ of the substrate of interest (Histone $\mathrm{H} 1$ for cdk2, Myelin Basic Protein for Erk 1 and 2, and Gst-c-Jun residues 1-79 for JNK1). The mixture was rocked for $45 \mathrm{~min}$ at room temperature, followed by centrifugation in a microfuge. The supernatant was run on $12.5 \%$ SDS-polyacrylamide gel and radioactivity was detected by autoradiography of the fixed gels.

\section{Cell cycle analysis}

For analysis of cell doubling times, trypsinized cells were plated on a 6 -well rat-tail collagen-coated plates at 10,000 cells per well and were cultured as indicated in the presence or absence of exogenous growth factors. At the indicated times, cells were removed from the plate with phosphate-buffered saline (PBS) containing trypsin-EDTA, and counted in a hematocytometer. To measure the cell cycle parameters, fluorescence activated cell sorting (FACS) was performed. To circumvent the problem of cell clumping during PC12 differentiation, nuclei were isolated from the cells prior to staining. Cells were grown in $150 \mathrm{~cm}$ plates, trypsinized, and centrifuged at $1000 \mathrm{rpm}$ for $10 \mathrm{~min}$. They were resuspended to a concentration of $2 \times 10^{6} \mathrm{cells} / \mathrm{ml}$ in a $4 \mathrm{mM}$ citrate buffer, $\mathrm{pH} 7.8$, containing $50 \mu \mathrm{g} / \mathrm{ml}$ of propidium iodide (PI, Sigma), 180 units/ml of RNase (Worthington), $0.1 \%$ Triton-X 100 , and $30 \mu \mathrm{g} / \mathrm{ml}$ polyethylene glycol (PEG). After a 20 min incubation at $37^{\circ} \mathrm{C}$, an equal volume of a $0.04 \mathrm{M} \mathrm{NaCl}$ buffer containing $50 \mu \mathrm{g} / \mathrm{ml} \mathrm{PI}, 0.1 \%$ Triton-X, and $30 \mathrm{mg} / \mathrm{ml} \mathrm{PEG}$ was added. The mixture was kept in the dark for at least $6 \mathrm{~h}$ at $4^{\circ} \mathrm{C}$. Cellular DNA was measured on a Coulter Eliter Analyzer using $488 \mathrm{~nm}$ excitation and a 630 long pass filter for the collection of PI fluorescence. The fluorescence was gated on single cells to minimize the effect of clumping on fluorescence intensity. Cell cycle analysis was performed with Multicycle software (Phoenix Flow Systems, San Diego, CA); the curve fitting program permitted the measurement of each phase of the cell cycle after the histograms were corrected for a background consisting of cellular debris.

\section{Acknowledgements}

We would like to thank Alvaro Montiero and Beatrice Knudsen for critical comments on the manuscript and Sanjay Chanriani for helpful discussions. We also thank Steve Denardo and Erica Matunis for assistance on the DAPI microscopy. RHG is a Howard Hughes Postdoctoral Research Fellow for Physicians. This work was supported in part by Public Health Service Grants GM-51446 (RBB), NS-30687 (BLH), GM-42461 (LS) and CA44356 (HH).

\section{References}

Barde Y (1989) Trophic factors and neuronal survival. Neuron 2: 1525-1534 Bertrand R, Solary E, O'Connor P, Kohn K and Pommier Y (1994) Induction of a common pathway of apoptosis by staurosporine. Experimental Cell Res. 211: 314-321

Bissonnette R, Echeverri F, Mahboudi A and Green D (1992) Apoptotic cell death induced by c-myc is inhibited by bcl-2. Nature 359: 552-554
Borasio GD, Markus A, Wittinghofer A, Barde YA and Heumann R (1993) Involvement of ras p21 in neurotrophin-induced response of sensory, but not sympathetic neurons. J. Cell Biol. 121: 665-672

Buchkovich KJ and Ziff EB (1994) Nerve growth factor regulates the expression and activity of $\mathrm{p} 33^{\mathrm{cdk} 2}$ and $\mathrm{p} 34^{\mathrm{cdc} 2}$ kinases in PC12 pheochromocytoma cells. Molecular Biol. Cell 5: 1225-1241

Cantley L, Auger K, Carpenter C, Duckworth B, Graziani A, Kapeller R and Soltoff S (1991) Oncogenes and signal transduction. Cell 64: 281-302

Estus S, Zaks WJ, Freeman RS, Gruda M, Bravo R and Johnson EM (1994) Altered gene expression in neurons during programmed cell death: identification of $c$-jun as necessary for neuronal apoptosis. Journal Cell. Biol. 127: 1717-1727

Evan G, Wyllie A, Gilbert C, Littlewood T, Land H, Brooks M, Waters C, Penn L and Hancock D (1992) Induction of apoptosis in fibroblasts by c-myc protein. Cell 69: $119-128$

Fath I, Schweighoffer F, Rey I, Multon M-C, Boiziau J, Duchesne M and Tocque B (1994) Cloning of a Grb2 isoform with apoptotic properties. Science 264: 971 974

Ferrari G, Anderson B, Stephens R, Kaplan D and Greene L (1995) Prevention of apoptotic neuronal death by GM1 ganglioside. J. Biol. Chem. 270: 3074-3080

Ferrari G and Greene LA (1994) Proliferative inhibition by dominant-negative Ras rescues naive and neuronally differentiated PC12 cells from apoptotic death. EMBO J. 13: 5922-5928

Freeman RS, Estus S and Johnson EM (1994) Analysis of cell cycle-related gene expression in postmitotic neurons: selective induction of cyclin D1 during programmed cell death. Neuron 12: 343-355

Garcia I, Martinou I, Tsujimoto Y and Martinou J (1992) Prevention of programmed cell death of sympathetic neurons by the bcl-2 proto-oncogene. Science 258 : $302-304$

Geer Pvd and Pawson T (1995) The PTB: a new protein module implicated in signal transduction. TIBS 20: $277-280$

Gomez-Pinilla F, Knauer DJ and Nieto-Sampedro M (1988) Epidermal growth factor receptor immunoreactivity in rat brain. Development and cellular localization. Brain Res. 438: 385-390

Gonzalex-Garcia M, Garcia I, Ding L, O'Shea S, Boise LH, Thompson CB and Nunez $\mathrm{G}$ (1995) bcl-x is expressed in embryonic and postnatal tissues and functions to prevent neuronal cell death. Proc. Natl. Acad. Sci. USA 92: 4304-4308

Greene $L$ and Tischler A (1976) Establishment of a noradrenergic clonal line of rat adrenal pheochromocytoma cells which respond to nerve growth factor. Proc. Natl. Acad. Sci. USA 73: 2424-2428

Greene L and Tischler A (1982) PC12 pheochromocytoma cultures in neurobiological research. Adv. Cell. Neurobiol. 3: 373-414

Ham J, Babii C, Whitfield J, Pfarr CM, Lallemand D, Yaniv M and Rubin LL (1995) A cJun dominant negative mutant protects sympathetic neurons against programmed cell death. Neuron 14: 927-939

Hempstead BL, Birge RB, Fajardo JE, Glassman R, Mahadeo D, Kraemer R and Hanafusa $\mathrm{H}$ (1994) Expression of the v-crk oncogene product in PC12 cells results in rapid differentiation by both nerve growth factor-and epidermal growth factor-dependent pathways. Mol. Cell. Biol. 14: 1964-1971

Hempstead BL, Rabin SJ, Kaplan L, Reid S, Parada LF and Kaplan DR (1992) Overexpression of the trk tyrosine kinase rapidly accelerates nerve growth factor-induced differentiation. Neuron 9: 883-896

Johnson NL, Gardner AM, Diener KM, Lange-Carter CA, Gleavy J, Jarpe MB, Minden A, Karin M, Zon LI and Johnson GL (1996) Signal transduction pathways regulated by mitogen-activated/extracellular response kinase induced cell death. J. Biol. Chem. 271: 3229-3237

Kaplan D, Hempstead B, Martin-Zanca D, Chao M and Parada L (1991) The trk protooncogene product: a signal transducing receptor for nerve growth factor. Science 252: $554-558$

Kaplan D and Stephens R (1994) Neurotrophin signal transduction by the trk receptor. J. Neurobiol. 25: 1404-1417

Klein R, Jing S, Nanduri V, O'Rourke E and Barbacid M (1991) The trk protooncogene encodes a receptor for nerve growth factor. Cell 65: 189-197

Kranenburg O, v d Eb AJ and Zantema A (1996) Cyclin D is an essential mediator of apoptotic neuronal cell death. EMBO J. 15: 46-54

Lindenboim L, Diamond R, Rothenberg E and Stein R (1995) Apoptosis induced by serum deprivation of $\mathrm{PC} 12$ cells is not preceeded by growth arrest and can occur at each phase of the cell cycle. Cancer Res. 55: 1242-1247 
Loeb DM and Greene LA (1993) Transfection with trk restores 'slow' NGF binding, efficient NGF uptake, and multiple NGF responses to NGF-nonresponsive PC12 cell mutants. J. Neuroscience 13: 2919-2929

Lowe SW, Ruley HE, Jacks T and Hous DE (1993) p53-dependent apoptosis modulates the cytotoxicity of anticancer agents. Cell 74: 957-967

Mah S, Zhong LT, Liu Y, Roghani A, Edwards R and Bredesen D (1993) The protooncogene bcl-2 inhibits apoptosis in PC12 cells. J. Neurochem. 60: $1183-$ 1186

Matsuda M, Hashimoto Y, Muroya K, Hasegawa H, Kurata T, Tanaka S, Nakamura S and Hattori S (1994) CRK protein binds to two guanine nucleotide-releasing proteins for the Ras family and modulates nerve growth factor-induced activation of Ras in PC12 cells. Mol. Cell. Biol. 14: 5495-5500

MayerB, Hamaguchi M and Hanafusa H (1988) A novel viral oncogene with structural similarity to phospholipase C. Nature 332: 272-275

Meikrantz W, Gisselbrecht S, Tam SW and Schlegel R (1994) Activation of cyclin Adependent protein kinases during apoptosis. Proc. Natl. Acad. Sci. USA 91: $3754-3758$

MesnerP, Winters T and Green S (1992) Nerve growth factor withdrawal-induced cell death in neuronal PC12 cells resembles that in sympathethic neurons. J. Cell. Biol. 119: 1669-1680

Motoyama N, Wang F, Roth KA, Sawa H, Nakayama K-i, Nakayama K, Negishi I, Senju S, Zhang Q, Fujii S and Loh DY (1995) Massive cell death of immature hematopoietic cells and neurons in Bcl-x-deficient mice. Science 267: $1506-$ 1510

Nicholson DW, Ali A, Thornberry NA, Vaillancourt JP, Ding CK, Gallant M, Gareau Y, Griffin P, Labelle M, Lazebnik YA, Munday NA, Raju SM, Smulson ME, Yamin TT, Yu VL and Miller DK (1995) Identification and inhibition of the ICE/CED-3 protease necessary for mammalian apoptosis. Nature 376: $37-43$

Obermeier A, Bradshaw R, Seedorf K, Choedas A, Schlessinger J and Ullrich A (1994) Neuronal differentiation signals are controlled by nerve growth factor receptor/Trk binding sites for SHC and PLC-gamma. EMBO J. 13: 1585-1590

Park D and Rhee S (1992) Phosphorylation of Nck in response to a variety of receptors, phorbol myristate acetate and cyclic AMP. Mol. Cell. Biol. 12: 5816 5823

Reichman C, Mayer B, Keshav S and Hanafusa H (1992) The product of the cellular crk gene consists primarily of $\mathrm{SH} 2$ and $\mathrm{SH} 3$ regions. Cell Growth Differ. 3: 451 460
Ren R, Mayer BJ, Cicchetti P and Baltimore D (1993) Identification of a 10-amino acid proline-rich SH3 binding site. Science 259: 1157-1161

Rozakis-Adcock M, McGlade J, Mbamalu G, Pelicci G, Daly R, Li W, Batzer A, Thomas S, Brugge J, Pelicci P, Schlessinger J and Pawson T (1992) Association of the Shc and Grb2/Sem5 SH2-containing proteins is implicated in activation of the Ras pathway by tyrosine kinases. Nature 360: 689-692

Rubin L, Philpott Kand Brooks S (1993) The cell cycle and cell death. Current Biol. 3: $391-394$

Rudkin BB, Lazarovici P, Levi B, Abe Y, Fujita K and Guroff G (1989) Cell cyclespecific action of nerve growth factor in PC12 cells: differentiation without proliferation. EMBO J. 8: 3319-3325

Rukenstein A, Rydel R and Greene L (1991) Multiple agents rescue PC12 cells from serum-free cell death by translation- and transcription-independent mechanisms. J. Neuroscience 11: 2552-2563

Sato N, Hotta K, Waguri S, Nitatori T, Tohyama K, Tsujimoto $Y$ and Uchiyama $Y$ (1994) Neuronal differentiation of PC12 cells as a result of prevention of cell death by bcl-2. J. Neurobiol. 25: 1227-1234

Stephens RM, Loeb DM, Copeland TD, Pawson T, Greene LA and Kaplan DR (1994) Trk receptors use redundant signal transduction pathways involving $\mathrm{SHC}$ and PLC-gamma to mediate NGF responses. Neuron. 12: 691-705

Teng KK, Landers H, Fajardo JE, Hanafusa H, Hempstead BL and Birge RB (1995) v Crkmodulation of growth factor-induced PC12 cell differentiation involves the src homology 2 domain of v-Crk and sustained activation of the Ras/Mitogenactivated protein kinase pathway. J. Biol. Chem. 270: 20677-20685

Thoenen H and Barde YA (1980) Physiology of nerve growth factor. Physiology Rev. 60: $1284-1335$

Tucker M, Eves EM, Wainer BH and Rosner MR (1994) Activation of mitogenactivated protein kinase by epidermal growth factor in hippocampal neurons and neuronal cell lines. J. of Neurochem. 61: 1376-1387

Xia Z, Dickens M, Raingeaud J, Davis R and Greenberg ME (1995) Opposing effects of ERK and JNK-p38 MAP kinases on apoptosis. Science 270: 1326-1331

Yao R and Cooper GM (1995) Requirement for phosphatidylinositol-3 kinase in prevention of apoptosis by NGF. Science 267: 2003-2006 